\title{
RESEARCH IN THEOLOGY IN THE DIGITAL AGE: OPPORTUNITIES AND LIMITATIONS
}

\begin{abstract}
Digital text repositories in the field of theology and history, including the works of John Calvin (1509-1564), are promising tools assisting scholars with comprehensive search capabilities, collaborative projects, annotations, and editing options. This paper discusses a case study of the opportunities and limitations of online scholarly archives of primary sources concerning the works of Calvin with particular attention to research, education, and publication. ${ }^{1}$
\end{abstract}

The phenomenal increase of digital archives in the field of humanities over the last decade has been nothing short of astounding. ${ }^{2}$ However promising these digital repositories may seem, a critical assessment of their opportunities and limitations for research, education, and publication is indispensable. The Europeana project currently includes over 15 million digital sources from over 1,000 archives in the European Union (Europeana 2011), the HathiTrust Digital Library, which preserves and provide access to material scanned by

1 This essay is an extended version of a paper delivered at the International Congress on Calvin Research, Bloemfontein, South Africa, August 22-27, 2010.

2 A digital archive is defined as a collection of digital resources, such as primary source text, focused on a specific area. Primary sources are understood in this paper as a first or later letterpress or a scholarly authoritative critical edition of printed material during the era of investigation. Secondary sources, then, provide interpretation and analysis of primary sources. All referenced websites have been accessed on October 10 and 11, 2011.

Adriaan C. Neele, Yale University, Research associate: Dpt. Church History and Polity, University of the Free State. E-mail: adriaan.neele@yale.edu.

Acta Theologica

2011 31(2): $190-200$

doi: http://dx.doi.org/10.4314/actat.v31i2.9

ISSN 1015-8758

@ UVIUFS

<http://www.uovs.ac.za/ActaTheologica> 
Google, the Internet Archive and other partner institutions include 9 million volumes (HathiTrust 2011), and the collaborative partnership of Google with the Universities of Michigan, Harvard, and Oxford has produced thus far over 15 million books online (Wikipedia 2011). Furthermore, national initiatives such as e-rara, a Swiss digital library dedicated to providing free online access to rare antique Swiss books and prints (E-rara 2011), and Gallica, a French collaborative project (Gallica 2011), contain millions of historical resources, such as books, manuscripts and maps previously only locally available. Concurrent with this extraordinary increase of digital resources is the fading away of early criticism about the quality of web-based historical resources for both commercial and open-access archives - though not without facing new inquiries about the creation, dissemination and preservation of scholarly digital archives (Jones 2007:1-10; 2008:54; Hadro 2008:25; Feijen \& Horstmann 2007:53; Heery \& Powel 2006:6-21; van den Sompel 2006:12). Furthermore, many projects of digital critical editions compete constantly for sufficient grant funding to sustain an open access policy, ${ }^{3}$ or have to seek for commercial alternatives to continue their scholarly endeavors.

These trends in the digital landscape impact and increasingly will impact the way of research, education and publication of theological studies, which can be illustrated by a case-study and survey of the works of the French / Swiss protestant reformer, preacher, teacher, pastor, and theologian John Calvin (1509-1564). His works, in part or whole, are now available through a growing number of various portals on the worldwide web, either as open access, such as the Bibliothèque Nationale de France (Gallica) (BNF), Bayerische Staats Bibliothek (BSB), e-rara, Internet Archive (IA), and Google Books $(G B)$, which all have been conveniently aggregated in the portal of the Post-reformation Digital Library (PRDL 2011) hosted by the H. Henry Meeter Center for Calvin Studies, or subscription-based, such as the Institute for Reformation Research at the Theological University of Apeldoorn (IRR), the Digital Library of Classic Protestant Texts (DLCPT), and Early English Books Online (EEBO). Although some students and scholars of Reformation studies, and Calvin studies in particular, are fairly at home in the digital world, others are bemused. Therefore a brief examination of a selected number of digital primary sources of Calvin, restricted to $16^{\text {th }}$ century editions - the Calvini Opera excepted, may suffice to acquaint one with the research opportunities and limitations both for open access and subscription based.

3 Open access (publishing) is defined as access to material (mainly scholarly publications) via the Internet in such a way that the material is free for all to read, and to use (or re-use) to various extents. 


\section{OPEN ACCESS: BNF, BSB, IA, E-RARA, AND GB.}

The Calvini Opera (Baum, Cunitz \& Reuss 1861-1900) is available at Open Archive at the University of Geneva (Open Archive 2011) and partially at GB (Google Books 2011) Access to the former initiates the downloading of the requested work - a step not required by $G B$, and constrained by available bandwidth. The accessed document, viewed as scanned pages of the original letterpress edition, can be searched for specific key words, whereby $G B$ presents all search results, highlighted in context by page number, which Open Archive offers one at a time. Although both venues offer download functionality (PDF format), the search function is lost with GB but remains functional in an Open Archive document. Furthermore, the entry of multiple words or phrase in the search field reveals that the search engine offers proximity in a sentence or paragraph. For example, the phrase "in summa" presents search results with the words "in" and "summa" sequential or separated by words, and sentences. In other words, the accuracy of the search results requires much discernment and interpretation of the user.

The works of Calvin digitally present in Latin, French and English at the $B N F$, such as Interim adultero-germanum (Calvin 1549), Defensio orthodoxae fidei de sacra Trinitate (Calvin 1554), and Le Catéchisme (Calvin 1552) and Sermons of upon the epistle to the Galathians (Calvin 1574) are only available in black / white image format, and search by words is not possible, though download in a PDF or JPEG format for research purposes is available to the user. Furthermore, Calvin's works published in the French language are listed in the $B N F$ but originates from e-rara Calvin 1548) and the $B S B$ (Calvin 1538). ${ }^{4}$ It presents the page image in color, and is non-searchable but downloadable, whereby the BSB contain works translated into German, and both contain various commentaries, sermons, treatises and other works. Finally, the $I A$ offers assorted Calvin works not only in various online formats, such as viewer, PDF - color and black / white, e-pub., Kindle, Daisy, DjVu and full text, whereby the read-online and both PDF versions are searchable - a functionality that remains after the PDF downloading.

These works then, available through open access, offer an entry globally to the rare editions of Calvin's work, which were previously only available locally. In some cases the work is presented with key word search functionality, and in other cases with high-quality digital scans in color - a laudable attempt to embody the original book enhancing the use of these digital primary sources. Furthermore, portals such as the PRDL, an aggregated website, greatly improve the accessibility, and foster a guided use of the various digital

4 This site offers various forms of locating a document such as browsing-index, name, period, and key word search, as well as translated works. 
resources of Calvin's work such as commentaries, sermons, doctrine, polemic, catechetical / liturgical, and correspondence (PRDL 2011).

\section{SUBSCRIPTION-BASED: DLCPT, EEBO AND IRR}

The DLCPT offers more than sixty selected works of Calvin, which are fully and advanced searchable, such as single term and phrase search, proximity searching in the same sentence or in the same paragraph on selected parts and the entire work or collective Calvin corpus; each work containing page images of the original letterpress edition connected to the searchable digital edition. Search results are presented in context or line by line, and in page order, and can be viewed by individual page, paragraph or section. The accuracy of the search result is highly precise, and offers the user the option to view the corresponding page image of the printed work in a separate window. Page images of printed works, though with various image quality and limited search capabilities is the core of the more than fifty English works of Calvin offered by EEBO. The Calvini Opera (CO) developed by IRR as fully searchable PDF's on compact disc formed the basis of a recent and promising initiative - the combination of a fully and advanced searchable $C O$ integrated with corresponding page image, like the DLCPT, and whereby specific works can be linked to digital editions that are available as open access documents. The user is then able to view the search result of, for example, the Interim Adultero-Germanum, as digital text, text image of the $C O$ and text image of the 1549 edition available through BNF (Calvin 1549). Furthermore, IRR envisions that the $C O$ is cross-searchable with other series of the Corpus Reformatorum, and other works of the sixteenth-century Reformation.

These works of Calvin, then, differentiate themselves primarily in their advance search capabilities and the level of precision of search results from the current open-access publications, as well as their ability to view the digitally formatted text with the corresponding page image. In this way, EEBO offers download functionality for licensed users, which option is currently not available by DLCPT and IRR.

This succinct survey shows the various and diverse digital primary sources of the works of this $16^{\text {th }}$-century Protestant Reformer. Although the majority of the commercially available digital works are still available only through sometimes cost-prohibitive user licensing, a more recent trend shows that open-access initiatives such as $G B, I A$, and e-rara make identical editions available. For example, the 1540 Commentarri in Epistolam Pauli as Romanos, previously available digitally through the DLCPT, is now freely accessible through IA (Calvin 1540). Other publications, such as the Defensio othodoxa 
fidei de sacra Trinitate, are now available through the DLCPT, BNF and $G B .^{5}$ Here, two observations are in order: first the search limitation of the open access archives remains a factor, but this might be temporary given the strong development efforts of advanced optical character recognition technology, including accurate identification of $16^{\text {th }}$ century letter types. However, if this trend continues, which is not unlikely, only the differentiating search functionality, quality of images, and user options could justify the continuation of restricted access. Furthermore, this trend shows also the complexity of the digital world, which may offer various outcomes for the deployment of these digital primary sources in research, education, and publication.

Concerning research, the current, and ever-increasing, number of available web-based primary sources present scholars and students of Calvin studies with advantages, such as local and round-the-clock availability of primary sources, building a personal library of digital sources for research purpose, and speedy locating of certain text(s) or phrases, previously part of a painstaking and time-consuming labor. However, these quickly generated search results must not only be judged on the accuracy of the primary source text but also on their lack in general of the surrounding text and accompanying argument of the author that is present in reading a tome physically in hands. Furthermore, the presentation of multiple search results of a certain word or phrase may assist the user in identifying possible connections of the author's flow of argument, yet one should exercise caution in constructing any initial conclusions from such search results (Hatch 2007:150-160; Maynard \& O'Brien 2010:400). For example, a key word search in Calvin's Psychopannychia (1534) on "anima" provides sixty-five occurrences in paragraph context, and reveals Calvin's use of the word in various ways. The search, however, neither takes into account the various declensions of the word, nor do the results give an immediate sense of the relationship, if any, to the main argument of the treatise. In short, the gain of access of the digital primary source may be tempered by the quality of the retrieved information, whereby the task of critical understanding and interpretation of the text remains with the reader.

In regard to education, those that teach Calvin studies should consider incorporating these digital primary sources in course curricula. Although the students, the next generation of Calvin scholars, are usually more acquainted with the digital world than the one currently teaching the subject matter, the exposure to primary source material offers new teaching opportunities. This is especially true for those countries that previously have been deprived of primary sources, and the ability to identify, contextualize, explore, analyze and evaluate the source (Walbert 2004; Anderson 2009:35-38; Johnston 5 An overview of all open access and commercial available works of Calvin can be
obtained from the author at adriaan.neele@yale.edu. 
2009:50-52; Ridgway 2009:60-61). The latter may be enhanced by comparing (digitally) such source with later editions, critical editions, and secondary sources. For example, Calvin's Acta Synodi Tridentinae is present at GB as the critical edition, the $C O(7: 365-506)$, whereby the text is accompanied with explanatory or interpretive notes, but also available as the 1547 edition at the $B S B$ and $I A$, without editorial apparatus (Calvin 1547). Such may assist students develop a more precise skill of a discerned reading of the primary text and editorial commentary, and enhance the quality of learning - though such learning does not ignore the pedagogical and didactical expediency of nonlinear reading of the codex book that so amazed St. Augustine (Grossman 2011:13). Furthermore, the increased use of e-learning applications offers ample opportunity to integrate the digital primary sources of Calvin's works into the study curriculum, which in that way also may contribute to a more eco-friendly learning environment by reduced paper use.

Finally, the use of digital primary sources will test new ways of citations, annotation, and open venues for publication in various forms such as e-journals and e-books, but also will present challenges of copyright and licensing guided or not by fair-use provisions. Despite these challenges, the Institut für Schweizerische Reformationsgeschichte, in conjunction with the Zwingliverein, recently launched a comprehensive, yet user-friendly academic and peer-reviewed e-journal (Zwingliana). Authors have the option to submit articles, and users can register to have free access to electronic published issues with a three year delay and will find more than 2,000 full text searchable articles in over 200 different issues of the journal since its founding in 1897. This form of publication, dedicated to Calvin studies, may foster an additional way of scholarly communication. ${ }^{6}$

\section{CONCLUSION}

In conclusion, the current developments in the digital landscape, including the field of theology, and in particular those related to the studies of Calvin's work by a continuing and increasing number of available primary sources, as well as a rising number of possibilities of making use of these sources, offer at the same time various opportunities and limitations, as the boundaries of scholarship, open access and commercial interest will continue to be tested, appropriated and defined. The rising number of early editions of the Geneva reformer available through open access shows concurrently a duplication of digitalization effort. Although the cost of digitalization may continue to decrease over time, a coordinated and cooperative initiative may lead to making more

6 Open Journal Systems is an open source journal application and a viable candidate to implement an e-journal for Calvin studies. 
works available, and optimizing hosting space and preservation. ${ }^{7}$ Furthermore, researchers should continue consulting commercial digital archives of Calvin resources, leveraging publications and editions that are not available through open access and making use of the advanced search capabilities such archives offer. In addition, the combination of different digital primary sources other than Calvin's text, such as, for example, digital cartography, historical records of the city of Geneva, and sixteenth-century publishers and printing houses may advance cross-disciplinary research, especially when crosscollection searches can retrieve collective results from such digital archives. Digital scholarly archive projects, such as First Source at the Jonathan Edwards Center at Yale University, promise advanced interplays between the Calvini and Melanchtoni Opera, the Edwards corpus, and Westminster Assembly records, thereby opening new ways of comparative research (First Source 2011).

The field of theology should make discriminated use of the new possibilities of digital research, education and publication to raise academic standards by internationally advancing thoughtful theological reflections through digital media.

\section{BIBLIOGRAPHY}

Allinson, J. \& Francois, S.

2008. SWORD: Simple Web-service Offering Repository Deposit Ariadne. [Online] Retrieved from: http://www.ariadne.ac.uk/issue54/allinson-et-al/

ANDERSON, M.A.

2009. The Power of Primary Sources, MultiMedia \& Internet@Schools 16(6):35-38.

CALVIN, J.

1538. Catechismus sive christianae religionis Institutio. Basel: n.p. [Onlline] Retrieved from: http://www.digitale-sammlungen.de/

1540. Commentarri in Epistolam Pauli as Romanos. Basel: n.p. [Online] Retrieved from: http://ia700504.us.archive.org/23/items/commentarijinepi00calv/ commentarijinepi00calv.pdf

1547. Acta Synodi Tridentinae cum Antidot per Ioann Caluinum. [Online] Retrieved from: http://www.digitalesammlungen.de/; http://books.google.com/ books? $\mathrm{id}=q S Y B A A A A Q A A J \&$ printse $=$ titlepage $\# v=$ onepage $\& q=$ synodi $\% 20$ tridentinae\&f=false; http://dfgviewer.de/show/?set[image]=41\&set[zoom]=defa ult\&set[debug] $=0 \&$ set[double]=0\&set[mets]=http\%3A\%2F\%2Fmdz10.bib-bvb.

7 Organizations such as International Congress on Calvin Research, Instituut voor Reformatie Onderzoek, H. Henry Meeter Center for Calvin Studies, and Institut für Schweizerische Reformationsgeschichte may consider to lead such initiative. 
de\%2F db\%2Fmets\%2Fbsb00027625_mets.xml; http://ia700301.us.archive. org/22/items/actasynoditriden00calv/actasynoditriden00calv.pdf

1548. Commentaire ... sur quatre Epistres de Sainct Paul. . Geneva: Jean Girard. [Online] Retrieved from: http://www.e-rara.ch/gep_g/content/titleinfo/282240

1548. Les Actes du Concile de Trente avec le remède . . Geneva: Jean Girard [Online] Retrieved from: http://www.e-rara.ch/gep_g/content/titleinfo/282242

1549. Commentaire ... sur l'Epistre aux Ebrieux. Geneva: Jean Girard. [Online] Retrieved from: http://www.e-rara.ch/gep_g/content/titleinfo/282243

1549. Interim adultero-Germanum, cui adiecta est vera Christianae pacificationis, et ecclesiae reformandae ratio. Geneva: Jean Girard. [Online] Retrieved from: http:// gallica.bnf.fr/ark:/12148/bpt6k53646p

1550. Institutio totius christianæ religioni. . . Geneva: Jean Girard. [Online] Retrieved from: http://www.e-rara.ch/gep_g/content/titleinfo/282246

1550. De scandalis . . Geneva: Jean Crespin. [Online] Retrieved from:.http:// www.e-rara.ch/gep_g/content/titleinfo/282245

1552. Catéchisme : c'est à dire, le formulaire d'instruire les enfants en la chrestienté, fait en la manière de dialogue, où le ministre interrogue et l'enfant respond. Geneve: Iehan Crespin. [Online] Retrieved from: http://gallica.bnf.fr/ark:/12148/bpt6k531151. $r=$ jean+calvin.langEN

1554. Defensio orthodoxae fidei de sacra Trinitate, contra prodigiosos errores Michaelis Serveti. Geneva: Oliua Roberti Stephani. [Online] Retrieved from: http:// gallica.bnf.fr/ark:/12148/bpt6k52707t

1558. Von der Papisten Heiligthumb. Pforzheim: G Raben. [Online] Retrieved from: http://www.digitale-sammlungen.de/

1572. Summarischer Begriff der lehr von den heiligen Sacramenten. Heidelberg: J. Maier. [Online] Retrieved from: http://www.digitale-sammlungen.de/

1574. Sermons of M. John Calvine upon the epistle of saincte Paule to the Galathians. London: Lucas Harison, 1574. [Online] Retrieved from: http://gallica. bnf.fr/ark:/12148/bpt6k536440.r=jean+calvin.langEN

1587. Predigten H. Iohannis Calvini vber das buch Job. Herborn, C. Raben. [Online] Retrieved from: http://www.digitale-sammlungen.de/

1597. Sermons de M. Jean Calvin sur le V. livre de Moyse nommé Deuteronome. Geneva: Thomas Courteau. [Online] Retrieved from: http://www.e-rara.ch/ doi/10.3931/e-rara-1057; http://gallica.bnf.fr/Search?ArianeWirelndex=index\&p=1 \&lang=EN\&q=jean+calvin $>$.

1863-1900. Opera Quae Supersunt Omnia. G. Baum, E. Cunitz, E. Reuss (eds.). Braunschweig: C.A. Schwetschke \& Son.

Corpus Reformatorum. Google Books. http://books.google.com/books?id=uykMAA

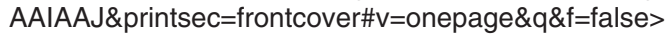


Digital Library of Classic Protestant Texts

2011. Digital Library of Classic Protestant Texts. [Online] Retrieved from: http:// solomon.tcpt.alexanderstreet.com

Early ENGLISH Books OnLINE

2011. Early English Books Online [Online] Retrieved from: http://eebo.chadwyck. com/home

E-RARA

2011. ETH-Bibliothek Zürich [Online] Retrieved from: http://www.e-rara.ch

EUROPEANA

2011. National Library of the Netherlands, The Hague. [Online] Retrieved from: http://www.europeana.eu/portal/aboutus.html

Feijen, M. \& Horstmann, W.

2007. DRIVER: Building the Network for Accessing Digital Repositories across Europe, Ariadne. [Online] Retrieved from: http://www.ariadne.ac.uk/issue53/feijenet-al/

FIRST SOURCE

2011. Jonathan Edwards Center, Yale University, New Haven. http://edwards.yale. edu/publication/first-source

GalLicA

2011. Bibliothèque national de France. [Online] Retrieved from: http://gallica.bnf.fr

Grossman, L.

2011. From Scroll to Screen, The New York Times Book Review, Sept.2, pp. 13.

HADRO, J.

2008. OCLC Offers Long-Term Digital Archive storage, Library Journal 133:9, 25.

HATCH, R.A.

2007. Primary Texts and Digital Research in Pre-1750 History of Science, Isis 98:150-160.

Hathi Trust Digital Library

2011. Hathi Trust Digital Library. [Online] Retrieved from: http://www.hathitrust.org

Heery, R. \& Powell, A.

2006. Digital Repositories Roadmap: looking forward, JISC. [Online] Retrieved from: www.jisc.ac.uk/uploaded_documents/rep-roadmap-v15.doc

JOHNSTON, M.P.

2009. A Historical Partnership: Teaching with Primary Sources. School Library Monthly 264:50-52.

JONES, C.

2007. Institutional Repositories: Content and Culture in an Open Access Environment. Oxford: Chandos Publishing. 
2008. Report of the Subject and Institutional Repositories Interactions Study, Science and Technology Facilities Council e-Science (Nov.).

Maynard, S. \& O'Brien, A.

2010. Scholarly output: print and digital in teaching and research. Journal of Documentation 66(3):400.

Open Archive

2011. University of Genève. [Online] Retrieved from: http://archive-ouverte.unige.ch

Open Journal Systems

2011. Public Knowledge Project. Simon Fraser University Vancouver. [Online] Retrieved from: http://pkp.sfu.ca/?q=ojs

Post Reformation Digital Library

n.d. Hekman Library, Grand Rapids, MI. [Online] Retrieved from: http://libguides. calvin.edu/content. php?pid=47579\&sid=578689

RIDGWAY, E.

2009. Teaching with Primary Sources: Professional Development from the Library of Congress at Your Fingertips. Knowledge Quest 38(2):60-61.

Van Den Sompel, H.

2006. An Interoperable Fabric for Scholarly Value Chains, Digital Library. [Online] Retrieved from: http://www.dlib.org/dlib/october06/vandesompel/10vandesompel. html>.

WALBERT, K.

2004. Reading primary sources: An introduction for students. [Online] Retrieved from: http://www.learnnc.org/lp/pages/745

WIKIPEDIA

2011. Google Books. [Online] Retrieved from: http://en.wikipedia.org/wiki/ Google_Books

ZWINGLIANA

2011. Swiss Reformation Studies Institute, University of Zurich. [Online] Retrieved from: http://www.zwingliana.ch/index.php/zwa/index

\section{LIST OF ABREVIATIONS USED}

BNF - Bibliothèque Nationale de France

BSB - Bayerisches Staats Bibliothek

DLCPT - Digital Library of Classic Protestant Texts

EEBO - Early English Books Online

GB - Google Books

IA - Internet Archive 
Neele

Research in Theology in the Digital Age

IRR - Institute for Reformation Research

PRDL - Post-Reformation Digital Library

Trefwoorde

Calvyn

Digitale bronne

Digitale navorsing
Keywords

Calvin

Digital resources

Digital research 